mgr inż. Anna MATEL

Wydział Ekonomii i Zarządzania, Uniwersytet w Białymstoku

e-mail: a.matel@uwb.edu.pl

DOI: $10.15290 /$ ose.2017.06.90.09

\title{
SYTUACJA MIESZKANIOWA GOSPODARSTW DOMOWYCH EMERYTÓW W POLSCE W LATACH 2009-2015
}

\begin{abstract}
Streszczenie
Celem opracowania jest ocena zmian w sytuacji mieszkaniowej gospodarstw domowych emerytów w Polsce w latach 2009-2015. Metodyka badań: W opracowaniu dokonano wyboru wskaźników obrazujących sytuację mieszkaniową gospodarstw domowych emerytów w Polsce. Dane podzielono na trzy kategorie, takie jak: warunki mieszkaniowe, sytuacja dochodowa oraz struktura demograficzna gospodarstw domowych. W analizie wykorzystano dane gromadzone przez Główny Urząd Statystyczny, w tym głównie wyniki badania budżetów gospodarstw domowych oraz raporty GUS w zakresie emerytur i rent w Polsce. Badania wykazały, że w obszarze warunków mieszkaniowych gospodarstw domowych emerytów w analizowanym okresie większość zmian miała pozytywny charakter. Negatywne zmiany - z punktu widzenia sytuacji mieszkaniowej - zaszły w obszarze struktury demograficznej gospodarstw domowych emerytów (zmniejszenie przeciętnej liczby osób w gospodarstwie domowym oraz wzrost udziału jednoosobowych gospodarstw domowych). W obszarze sytuacji ekonomicznej część zmian (w tym dotycząca poziomu emerytur w relacji do średniego poziomu dochodów w gospodarce narodowej) była pozytywna. Jednak zaszły negatywne zmiany w zakresie zadłużenia, związanego z użytkowaniem mieszkania.
\end{abstract}

Słowa kluczowe: srebrna gospodarka, senior, ludzie starsi, starzenie się populacji, rynek mieszkaniowy, potrzeby mieszkaniowe

HOUSING SITUATION OF PENSIONER HOUSEHOLDS IN POLAND, 2009-2015

\section{Summary}

The purpose of this study is to investigate changes in the housing situation of pensioner households in Poland in 2009-2015. The author identifies indicators describing the housing situation of Polish pensioners, dividing them into three categories: housing conditions, economic situation, and demographic structure of pensioner households. The variation coefficient of most indicators was found to be low. The analysis is based on data from the Central Statistical Office, mainly on the results of a survey concerning household budgets and reports regarding pensions in Poland. The research indicates that most of the changes are positive in the area of the level of satisfying pensioners' housing needs. There were negative changes in the demographic structure of pensioner households (lower average number of persons per household and higher percentage of single-person households). As far as economic situation is concerned, some of the changes (including the level 
of income in relation to the average income in the national economy) are positive. However, negative changes occurred in the level of households' debt related to housing maintenance.

Key words: silver economy, senior, elderly people, aging of the population, housing market, housing needs

JEL Classification: R30, D31, J14

\section{Wstęp}

W ostatnich latach działania z zakresu polityki mieszkaniowej koncentrowały się głównie na zwiększaniu dostępności mieszkań dla osób młodych oraz nowych gospodarstw domowych przez realizację takich programów, jak „Rodzina na Swoim” i „Mieszkanie dla Młodych" [Marcinkiewicz, Matel, 2017]. Jednak obecnie istotną kwestią staje się sytuacja mieszkaniowa osób starszych. Aktualnie problem ten stanowi przedmiot dyskusji w ramach kształtowania polityki społecznej i gospodarczej większości krajów średnio i wysoko rozwiniętych w ramach koncepcji silver economy. Wynika to z postępujących procesów starzenia się społeczeństwa, które można zdefiniować jako: zwiekeszanie odsetka osób starszych pray jednoczesnym zmniejszaniu odsetka dzieci [Prognoza ludności..., 2014, s. 126]. Prognozy demograficzne wskazuja, że udział osób w wieku emerytalnym w Polsce będzie systematycznie rósł. Niska dzietność oraz bardzo niski bądź nawet ujemny przyrost naturalny, w połączeniu z korzystnymi zmianami w zakresie długości życia, przekładają się na wzrost udziału osób starszych w strukturach społecznych. Jest to zjawisko charakterystyczne dla większości krajów Unii Europejskiej. W 2015 roku odnotowano sumaryczny, ujemny przyrost naturalny dla krajów Unii Europejskiej, przy czym przyjmował on ujemne wartości w połowie krajów UE28, w tym w Polsce [http:/ / appsso.eurostat.ec.europa.eu]. To z kolei oddziałuje na wzrost udziału osób starszych w strukturach społecznych oraz obciążenie ludności w wieku produkcyjnym ludnością w wieku poprodukcyjnym, który średnio w krajach UE28 wynosił 28,8, natomiast najwyższe wartości przyjął w Niemczech (32), Grecji $(32,4)$, Włoszech $(33,7)$, zaś najniższe na Słowacji (19,7), w Luksemburgu $(20,5)$ i w Irlandii (20). Wskaźnik w Polsce w 2015 roku wyniósł 22,2 i ukształtował się znacznie poniżej średniej dla krajów Unii Europejskiej.

Problem nasila się w krajach o wysokiej emigracji, która powoduje odpływ osób młodych, w wieku produkcyjnym, co zarówno wpływa na strukturę demograficzna, jak i ogranicza możliwość bezpośredniego wsparcia rodzinnego osób starszych.

W Polsce w 1950 roku na 100 osób w wieku produkcyjnym przypadało 12 osób w wieku poprodukcyjnym, a odsetek osób w wieku 0-14 lat przewyższał niemal sześciokrotnie odsetek osób starszych (w wieku powyżej 65. roku życia). Sytuacja zaczęła ulegać zmianie w latach sześćdziesiątych XX wieku. Dysproporcja między liczbą osób najmłodszych a najstarszych zaczęła spadać. W 2010 roku osoby w wieku do 14 lat stanowily $15,2 \%$ społeczeństwa polskiego, a osoby w wieku powyżej 65 . roku życia -13,5\%. Od 2015 roku sytuacja zmieniła się i liczba osób starszych w społeczeństwie polskim przekroczyła liczbę osób w wieku do 14 lat. Prognozy GUS świadczą o tym, 
że do 2050 roku liczba osób w wieku 65+ w porównaniu z 2015 rokiem podwoi się, zaś spadnie liczba osób w pozostałych grupach wiekowych. Według prognoz GUS, do 2050 roku udział osób w wieku 65+ w polskim społeczeństwie wzrośnie do 32,7\% [Rocznike demograficzny..., 2016].

Rosnący udział osób starszych wynika ze zmiany tradycyjnej formy rodziny, spadającej dzietności, z wkraczania osób z powojennego wyżu demograficznego w okres emerytalny, jak również z wydłużania się przeciętnej długości życia. W 2015 roku dla kobiet wskaźnik przeciętnego dalszego trwania życia wynosił 81,57 lat, natomiast dla mężczyzn 73,58 lata i rósł od 2000 roku średnio o jeden rok życia w ciągu pięciu lat [Rocznike demograficzny..., 2016].

Wpływ starzenia się społeczeństwa na kształtowanie polityki mieszkaniowej w kraju w ostatnich latach jest dostrzegany na poziomie projektowania polityki społecznej. 11 września 2015 roku Sejm uchwalił ustawę o osobach starszych (Dz. U. 2015, poz. 1705) określająca zakres monitorowania ich sytuacji, wliczając w to warunki mieszkaniowe (art. 3). Jednym z priorytetów podjętej 27 września 2016 roku przez Radę Ministrów uchwały o przyjęciu Narodowego Programu Mieszkaniowego jest opracowanie polityki senioralnej. Jako jeden z celów Deklaracji Programowej Rozwoju Gospodarki Senioralnej w Polsce z 1 lutego 2016 roku określono wspieranie inicjatyw w celu poprawy jakości życia seniorów mieszkających w miastach i na terenach niezurbanizowanych dzięki wspieraniu rozwoju różnych form mieszkalnictwa dla seniorów. Z tego względu kwestia sytuacji mieszkaniowej osób starszych, w tym poprzez jej monitorowanie, staje się istotnym obszarem badań. W związku z tym, celem opracowania jest ocena zmian w sytuacji mieszkaniowej gospodarstw domowych emerytów w Polsce w latach 2009-2015.

\section{Metodyka badań}

Ocena sytuacji mieszkaniowej seniorów w Polsce w obliczu rozproszenia danych statystycznych, a także potrzeby uwzglednienia zarówno zmiennych ilościowych, jak i jakościowych [Zrałek, 2014, s. 104] nie jest zadaniem prostym. W szczególności dane jakościowe są trudne w pomiarze i ocenie, najczęściej nie posiadają charakteru danych ciagłych, nie pozwalają więc na ocenę zmian w ujęciu dynamicznym. Podstawowym źródłem danych umożliwiającym prowadzenie takich analiz są wyniki badania budżetów gospodarstw domowych oraz raporty dotyczące rent i emerytur w Polsce, prowadzone cyklicznie przez Główny Urząd Statystyczny.

Podejmując próbę oceny sytuacji mieszkaniowej gospodarstw domowych emerytów, wyodrębniono trzy obszary analizy, takie jak:

- sytuacja demograficzna gospodarstwa domowego,

- sytuacja dochodowa gospodarstwa domowego,

- warunki mieszkaniowe.

W każdym obszarze dokonano analizy wybranych zmiennych, aby wyznaczyć kierunek zmian zachodzących w badanym okresie. Zmienne w większości przypadków 
były nisko zróżnicowane (co jest charakterystyczne dla badania zmian w zakresie sytuacji mieszkaniowej). W związku z tym, zrezygnowano z budowy syntetycznego miernika oceny. Dążono do określenia kierunku zmian w poszczególnych obszarach. Zmienne wyznaczono, jako stymulanty lub destymulanty sytuacji mieszkaniowej osób starszych oraz wskazano ich wpływ w badanym okresie na sytuację mieszkaniową emerytalnych gospodarstw domowych.

Wybór trzech obszarów analizy, w celu ustalenia zmian w zakresie sytuacji mieszkaniowej gospodarstw domowych emerytów, wynika z silnych powiązań sytuacji demograficznej i ekonomicznej z warunkami mieszkaniowymi, będącymi w pewnym sensie ich konsekwencja. W równej mierze sytuacja demograficzna, jak i dochodowa gospodarstw domowych warunkuje możliwość zaspokajania potrzeb mieszkaniowych w gospodarstwie domowym. Zarówno obecny poziom dochodów, jak i ich spadek po przejściu na emeryturę decydują o zdolności gospodarstwa domowego do regulowania bieżących zobowiązań dotyczących utrzymania mieszkania oraz zapewnienia odpowiednich warunków mieszkaniowych. Sytuacja dochodowa gospodarstw domowych wpływa na zdolność do ponoszenia bieżących kosztów utrzymania mieszkania, jak również spłaty zobowiązań. Sytuacja mieszkaniowa emerytalnych gospodarstw domowych jest silnie związana z sytuacją demograficzna. Liczba osób w gospodarstwie domowym $z$ jednej strony oddziałuje na komfort mieszkaniowy, $z$ drugiej wiąże się z rosnącymi kosztami użytkowania mieszkania, natomiast stan zdrowia emerytów decyduje o ich zdolności do utrzymania samodzielności w mieszkaniu.

W badaniu wykorzystano dane z raportów GUS na temat rent i emerytur w Polsce, w tym ze sprawozdawczości: Zakładu Ubezpieczeń Społecznych, Kasy Rolniczego Ubezpieczenia Społecznego oraz Instytutu Pracy i Spraw Socjalnych, a także dane z roczników demograficznych GUS. Szczególnie istotne były dane na temat wyników badania budżetów gospodarstw domowych prowadzonych przez GUS za pomocą metody reprezentacyjnej, co stwarza możliwość uogólnienia uzyskanych wyników. Ze względu na dostępność analizowanych danych, okres badania zawężono do lat 2009-2015.

Badaniem objęto gospodarstwa domowe emerytów. Te są definiowane jako gospodarstwa domowe, których wyłącznym lub głównym (przeważającym) źródłem utrzymania jest emerytura, zaś dodatkowym źródłem utrzymania może być: inne źródło niezarobkowe poza emeryturą (np.: dochód z własności, zasiłki rodzinne wraz z dodatkami, dary), praca najemna, praca na własny rachunek bądź wykonywanie wolnego zawodu, co oznacza, że dochody uzyskiwane ze źródeł dodatkowych są niższe od dochodów uzyskiwanych z emerytur [Emerytury $i$ renty...].

\section{Struktura demograficzna gospodarstw domowych emerytów w latach 2009-2015}

W pierwszym badanym obszarze (sytuacja demograficzna gospodarstw domowych emerytów) przeanalizowano: udział w populacji osób w wieku powyżej 65. roku życia, 
liczbę osób przypadającą na jedno gospodarstwo domowe emerytów, odsetek jednoosobowych gospodarstw domowych emerytów, a także odsetek osób, które subiektywnie oceniają swój stan zdrowia jako zły lub bardzo zły.

W badanym okresie w polskim społeczeństwie odsetek osób w wieku powyżej 65. roku życia wzrósł z 13,5 do 15,8\%. Wiąże się to z postępującym procesem starzenia się społeczeństwa. Kwestia ta jest istotna dla kształtowania sytuacji mieszkaniowej emerytów ze względu na niski stan dostosowania mieszkań do potrzeb starzejącego się społeczeństwa ${ }^{1}$.

Liczba osób w gospodarstwach domowych emerytów okazała się znacznie niższa niż w większości gospodarstw domowych. W 2015 roku przeciętne gospodarstwo domowe emerytów składało się średnio z 1,93 osoby, przy wskaźnikach na poziomie 3,16-3,87 w pozostałych grupach gospodarstw domowych. W badanym okresie odnotowano spadek liczby osób w gospodarstwach domowych emerytów z poziomu 2,02 w 2009 roku do 1,94 w 2015 roku (tabela 1.), przy jednoczesnym wzroście liczby gospodarstw domowych jednoosobowych.

TABELA 1. Struktura demograficzna gospodarstw domowych emerytów w Polsce w latach 2009-2015

\begin{tabular}{|c|c|c|c|c|c|}
\hline Rok & $\begin{array}{c}\text { \% osób } \\
\text { w wieku } \\
\text { 65+ (x1) }\end{array}$ & $\begin{array}{c}\text { liczba osób } \\
\text { wospodarstwie } \\
\text { domowym }\end{array}$ & $\begin{array}{c}\text { \% gospodarstw domowych } \\
\text { jednoosobowych } \\
\text { (x2) }\end{array}$ & dwuosobowych & $\begin{array}{c}\text { \% emerytów } \\
\text { oceniających swój } \\
\text { stan zdrowia jako } \\
\text { zły lub bardzo zły } \\
\text { (x3) }\end{array}$ \\
\hline 2009 & 13,5 & 2,02 & 32,13 & 48,57 & 34,3 \\
2010 & 13,5 & 2,01 & 31,97 & 48,59 & 33,4 \\
2011 & 13,8 & 2,03 & 30,79 & 49,11 & 31,5 \\
2012 & 14,2 & 1,99 & 32,56 & 48,84 & 30,2 \\
2013 & 14,7 & 1,96 & 33,91 & 48,48 & 28,6 \\
2014 & 15,3 & 1,94 & 34,55 & 48,33 & 27,6 \\
2015 & 15,8 & 1,94 & 33,73 & 50,15 & 27,8 \\
\hline
\end{tabular}

Źródło: opracowanie własne na podstawie: [Emerytury i renty..., 2009, 2010, 2011, 2012, 2013, 2014, 2015; Rocznik Statystyczny Rzeczpospolitej Polskiej..., 2009, 2010, 2011, 2012, 2013, 2014, 2015; Rocznik demograficzny Rzueczpospolitej Polskiej..., 2009, 2010, 2011, 2012, 2013, 2014, 2015].

W 2015 roku ponad co trzecie emerytalne gospodarstwo domowe funkcjonowało jako gospodarstwo jednoosobowe. Wzrósł również udział gospodarstw domowych dwuosobowych. Zmiany takie stanowią istotną kwestię ze względu na sytuację dochodową. Przeciętne miesięczne wydatki na 1 osobę w gospodarstwach domowych emerytów w 2015 roku wyniosły dla gospodarstw jednoosobowych - 1 571,25 zł, dla

1 Problem ten ujawnily m.in. wyniki badania PolSenior [www.polsenior.iimcb.gov.pl]. 
dwuosobowych - 1 309,02, zaś dla trzyosobowych - 1 086,66 zł [Rocznik Statystyczny..., 2016, s. 287]. Gospodarstwa domowe emerytów o mniejszej liczbie osób miały więc wyższe koszty utrzymania w przeliczeniu na osobę. Tym samym przy jednakowych dochodach gospodarstwa domowe o mniejszej liczbie osób posiadały mniejszą zdolność do regulowania bieżących zobowiązań. W związku z tym, wraz ze spadkiem liczby osób w gospodarstwie domowym zmniejszała się zdolność do finansowania bieżących wydatków.

W 2009 roku swój stan zdrowia jako zły lub bardzo zły oceniało 34,3\% emerytów, zaś w 2015 - niespełna 28\%. Jednocześnie wzrósł udział emerytów oceniających stan zdrowia jako dobry bądź bardzo dobry (25,2 w 2009 roku, 30,2\% w 2015 roku). Z punktu widzenia polityki mieszkaniowej jest to pozytywna zmiana ze względu na możliwość dłuższego utrzymania samodzielności emerytów oraz pozostania w mieszkaniu (zgodnie z koncepcja aging in place).

W tabeli 2. zestawiono zmienne uznane za najważniejsze dla zobrazowania sytuacji demograficznej gospodarstw domowych emerytów w badanym okresie, wskazują ich zmiany oraz wpływu na sytuację mieszkaniową badanych gospodarstw domowych.

TABELA 2.

Podstawowe zmienne obrazujące sytuację demograficzną gospodarstw domowych emerytów w Polsce w latach 2009-2015

\begin{tabular}{|l|c|c|c|c|c|}
\hline Zmienna & $\begin{array}{c}\mathbf{2 0 0 9} \\
\mathbf{( w} \% \mathbf{~})\end{array}$ & $\begin{array}{c}\mathbf{2 0 1 5} \\
\mathbf{( w} \mathbf{0})\end{array}$ & $\begin{array}{c}\text { Zmiana w ba- } \\
\text { danym okresie } \\
\text { (w pp.) }\end{array}$ & $\begin{array}{c}\text { Wpływ na sytua- } \\
\text { cję mieszkaniową }\end{array}$ & $\begin{array}{c}\text { Ocena } \\
\text { zmiany }\end{array}$ \\
\hline $\mathrm{x} 1$ & 13,5 & 15,8 & $+2,30$ & $\mathrm{~d}$ & - \\
$\mathrm{x} 2$ & 32,13 & 33,73 & $+1,60$ & $\mathrm{~d}$ & - \\
$\mathrm{x} 3$ & 34,3 & 27,8 & $-6,50$ & $\mathrm{~d}$ & + \\
\hline
\end{tabular}

gdzie: s - stymulanta, d - destymulatna, „,+" - wpływ pozytywny, „, " - wpływ negatywny, x1-x4 - według znaczeń w tabeli 1

Źródło: opracowanie własne na podstawie: [Emerytury i renty..., 2009, 2010, 2011, 2012, 2013, 2014, 2015; Rocznite Statystyczny..., 2009, 2010, 2011, 2012, 2013, 2014, 2015; Rocznik demografičny..., 2009, 2010, 2011, 2012, 2013, 2014, 2015].

Ogółem w badanym okresie sytuacja demograficzna gospodarstw domowych emerytów w Polsce uległa pogorszeniu pod względem jej wpływu na sytuację mieszkaniowa. Od 2009 roku systematycznie spadała liczba osób w gospodarstwach domowych emerytów, co głównie było spowodowane wzrostem odsetka gospodarstw jednoosobowych. Jednocześnie rosnący udział osób w starszym wieku powoduje, że kwestia zaspokajania potrzeb mieszkaniowych tej grupy społeczeństwa staje się istotnym problemem społecznym. Pozytywną zmianą w analizowanym okresie była poprawa subiektywnie ocenianego stanu zdrowia emerytów. To natomiast może sprzyjać rozwojowi instrumentów senioralnej polityki mieszkaniowej, zgodnych z koncepcja utrzymania samodzielności w miejscu zamieszkania. 


\section{Sytuacja dochodowa gospodarstw domowych emerytów w latach 2009-2015}

Drugim obszarem badań była sytuacja dochodowa gospodarstw domowych emerytów w Polsce. W tym obszarze przeanalizowano takie zmienne, jak: relacja przeciętnej miesięcznej emerytury brutto z pozarolniczego systemu ubezpieczeń społecznych oraz z Kasy Rolniczego Ubezpieczenia Społecznego (KRUS) do przeciętnego wynagrodzenia w gospodarce narodowej, relacja przeciętnego miesięcznego dochodu rozporządzalnego do średniego minimum socjalnego dla gospodarstw emeryckich, udział wydatków na użytkowanie mieszkania i nośniki energii w ogóle wydatków, zdolność do pokrywania zobowiązań finansowych związanych z użytkowaniem mieszkania.

W tabeli 3. przedstawiono relację przeciętnej miesięcznej emerytury brutto z pozarolniczego systemu ubezpieczeń społecznych do przeciętnego wynagrodzenia w gospodarce narodowej (x5) oraz relację przeciętnej miesięcznej emerytury brutto z Kasy Rolniczego Ubezpieczenia Społecznego do przeciętnego wynagrodzenia w gospodarce narodowej (x6).

TABELA 3.

Relacja przeciętnej miesięcznej emerytury brutto z pozarolniczego systemu ubezpieczeń społecznych oraz z Kasy Rolniczego Ubezpieczenia Społecznego do przeciętnego wynagrodzenia w gospodarce narodowej w latach 2009-2015

\begin{tabular}{|c|c|c|}
\hline Rok & $\begin{array}{c}\text { Relacja przeciętnej miesięcznej } \\
\text { emerytury brutto z pozarolni- } \\
\text { czego systemu ubezpieczeń } \\
\text { społecznych do przeciętnego } \\
\text { wynagrodzenia w gospodarce } \\
\text { narodowej (w \%) }\end{array}$ & $\begin{array}{c}\text { Relacja przeciętnej miesięcznej } \\
\text { emerytury brutto z Kasy Rolni- } \\
\text { czego Ubezpieczenia Społecz- } \\
\text { nego do przeciętnego wynagro- } \\
\text { dzenia w gospodarce narodo- } \\
\text { wej (w \%) }\end{array}$ \\
\hline 2009 & 60,8 & 35 \\
2010 & 62,2 & 35,3 \\
2011 & 62 & 34,6 \\
2012 & 62,9 & 35,6 \\
2013 & 64 & 36,1 \\
2014 & 64 & 35,6 \\
2015 & 63,7 & 35,5 \\
\hline
\end{tabular}

Źródło: opracowanie własne na podstawie: [Emerytury i renty..., 2009, 2010, 2011, 2012, 2013, 2014, 2015].

Poziom przeciętnej emerytury brutto w Polsce był znacznie niższy od poziomu przeciętnego wynagrodzenia w gospodarce narodowej. Szczególnie silnie uwidoczniła się różnica w poziomie tej relacji w odniesieniu do emerytury z Kasy Rolniczego Ubezpieczenia Społecznego, która stanowiła w 2015 roku trzecią część przeciętnego 
wynagrodzenia. Przeciętna emerytura z pozarolniczego systemu ubezpieczeń społecznych w 2015 roku wyniosła 63,7\% przeciętnego wynagrodzenia w gospodarce narodowej. To zaś wskazuje, że w szczególnie trudnej sytuacji dochodowej znajdują się gospodarstwa domowe emerytów mieszkających na wsiach. Pomimo braku drastycznych zmian, w ostatnich latach różnice w relacji emerytur z pozarolniczego systemu ubezpieczeń społecznych oraz z Kasy Rolniczego Ubezpieczenia Społecznego do przeciętnego wynagrodzenia w gospodarce narodowej systematycznie pogłębiają się. W 2009 roku wynosiły 25,8 pp., zaś w 2015 roku 28,2 pp. Ogółem w analizowanym okresie zmniejszyła się różnica między wartością przeciętnej emerytury a przeciętym wynagrodzeniem w gospodarce narodowej, co jest zmiana pozytywną. Równocześnie jednak pogłębiły się różnice w dochodach emerytów otrzymujących świadczenia z KRUS oraz ZUS.

Pozytywne zmiany odnotowano w zakresie relacji przeciętnego miesięcznego dochodu rozporządzalnego na 1 osobę w gospodarstwach domowych emerytów (w zł) do średniego minimum socjalnego dla jednoosobowych gospodarstw emeryckich ${ }^{2}(\mathrm{x} 7)$.

WYKRES 1.

Relacja przeciętnego miesięcznego dochodu rozporządzalnego na 1 osobę w gospodarstwach domowych emerytów (w zł) do średniego minimum socjalnego dla jednoosobowych gospodarstw emeryckich

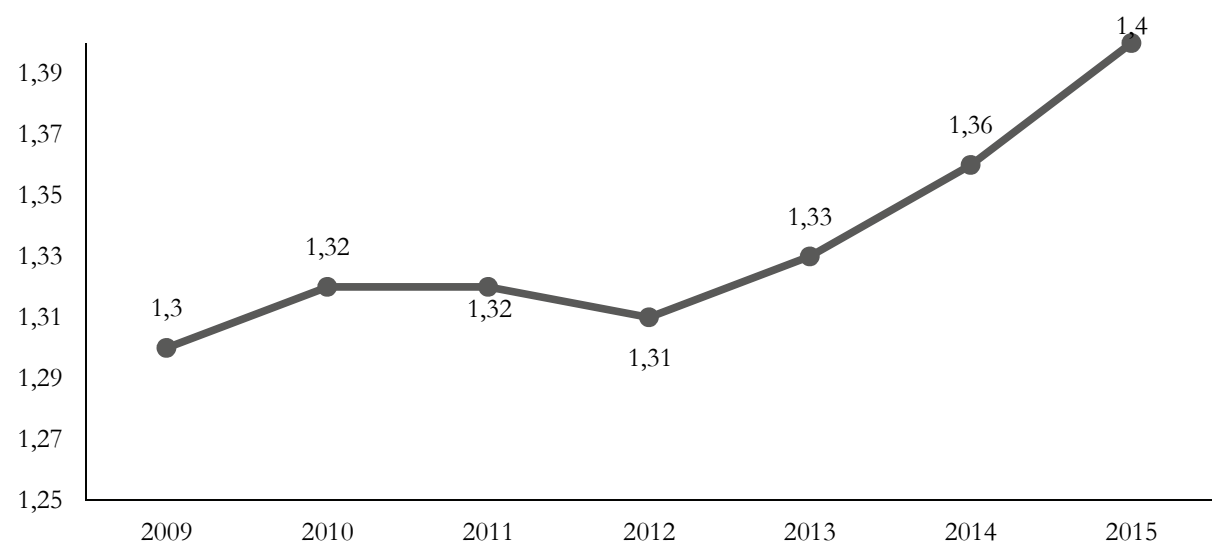

Źródło: opracowanie własne na podstawie: [Emerytury i renty..., 2009, 2010, 2011, 2012, 2013, 2014, 2015].

Wskaźnik ten w 2009 roku wyniósł 1,30 (wykres 1.). Oznacza to, że przeciętny dochód rozporządzalny na 1 osobę w gospodarstwach domowych emerytów był wyższy o 30\% od minimum socjalnego liczonego dla jednoosobowych gospodarstw domowych emerytów. W kolejnych latach następowała sukcesywna poprawa wskaźnika,

2 Jest to kwota ustalana każdego roku przez Instytut Pracy i Spraw Socjalnych na podstawie normatywnego modelu zaspokajania potrzeb bytowo-konsumpcyjnych na niskim poziomie, przyjmujacego postać „koszyków”, określonych ilościowo i wartościowo dla poszczególnych grup potrzeb. 
poza niewielkim spadkiem odnotowanym w 2012 roku. Ostatecznie w 2015 roku przeciętny dochód rozporządzalny był wyższy o 40\% od minimum socjalnego.

W analizowanym okresie zaobserwowano wahania dotyczące udziału wydatków mieszkaniowych w ogóle wydatków emerytalnych gospodarstw domowych (x8).

WYKRES 2.

Udział przeciętnych miesięcznych wydatków na użytkowanie mieszkania i nośniki energii na 1 osobę w gospodarstwach domowych emerytów w ogóle wydatków

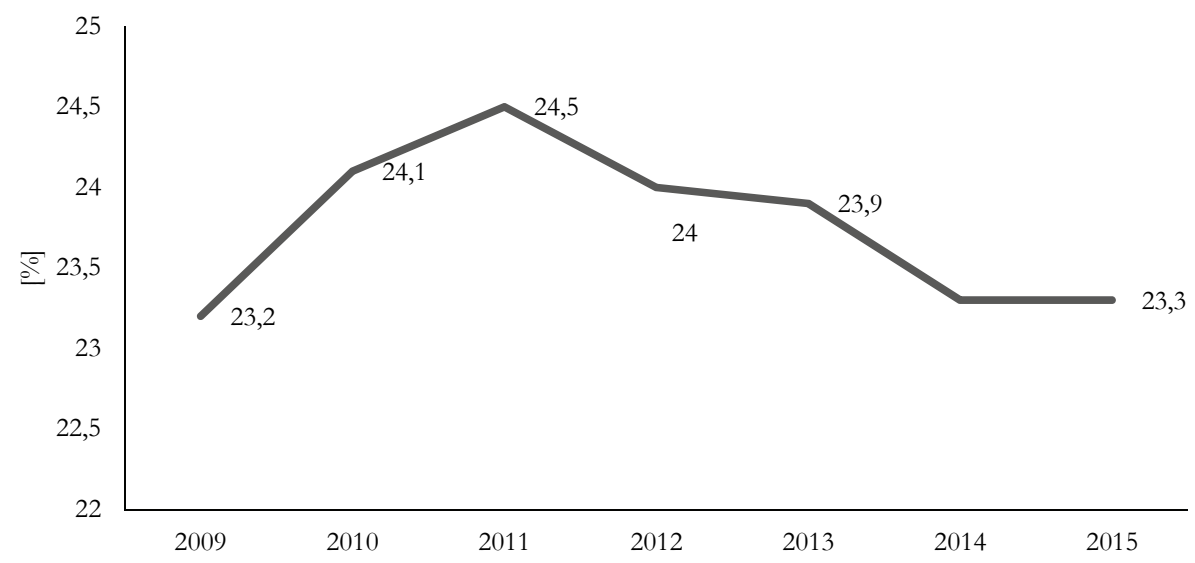

Źródło: opracowanie własne na podstawie: [Emerytury i renty..., 2009, 2010, 2011, 2012, 2013, 2014, 2015].

Udział wydatków na użytkowanie mieszkania i nośniki energii w przeliczeniu na jedną osobę w gospodarstwach domowych emerytów w ogóle wydatków w analizowanym okresie przejawiał wahania, jednak ostatecznie nieznacznie wzrósł. W latach 2009-2011 stwierdzono wzrost o 1,3 pp., z poziomu 23,2 do 24,5 \% (wykres 2.). Od 2011 roku odnotowuje się systematyczny spadek wskaźnika. Ogółem, po wahaniach w 2015 roku, udział ten wrócił do poziomu z 2009 roku (zmiana o 0,1 pp.).

Kolejnym wskaźnikiem było wywiązywanie się gospodarstw domowych emerytów z zobowiązań finansowych (tabela 4.). 
TABELA 4.

Odsetek gospodarstw domowych emerytów niewywiązujących się z opłat związanych z użytkowaniem mieszkania z powodu problemów finansowych

\begin{tabular}{|c|c|c|c|}
\hline \multirow{2}{*}{ Rok } & $\begin{array}{c}\text { \% gospodarstw domowych emerytów deklarujących, że w roku poprzedzającym } \\
\text { badanie ze względu na problemy finansowe przynajmniej raz nie udało się uiścić } \\
\text { w terminie: }\end{array}$ \\
\cline { 2 - 4 } & $\begin{array}{c}\text { stałych opłat związanych } \\
\text { z użytkowaniem miesz- } \\
\text { kania (gaz, woda, elek- } \\
\text { tryczność) }\end{array}$ & $\begin{array}{c}\text { spłat rat kredytu hipo- } \\
\text { tecznego na użytkowane } \\
\text { mieszkanie }\end{array}$ & $\begin{array}{c}\text { spłat rat kredytów, poży- } \\
\text { czek innych niż kredyt } \\
\text { hipoteczny na użytko- } \\
\text { wane mieszkanie }\end{array}$ \\
\hline 2009 & 7,1 & 0 & 8 \\
2010 & 8,2 & 4,8 & 10 \\
2011 & 8,1 & 4,7 & 9,7 \\
2012 & 7,9 & 6,4 & 10,3 \\
2013 & 8,1 & 3 & 14,2 \\
$2014^{*}$ & 8 & 2,9 & 9 \\
\hline
\end{tabular}

* brak danych za 2015 rok

Źródło: opracowanie własne na podstawie: [Emerytury i renty..., 2009, 2010, 2011, 2012, 2013, 2014, 2015].

W analizowanym okresie wzrósł odsetek osób deklarujących, że w roku poprzedzającym badanie ze względu na problemy finansowe przynajmniej raz nie udało się uiścić w terminie stałych opłat związanych z użytkowaniem mieszkania, takich jak: gaz, woda, elektryczność (x9). Odsetek ten w 2009 roku wynosił 7,1\%, po czym w badanym okresie przejawiał wahania, jednak ostatecznie odnotowano jego wzrost ( $8 \% \mathrm{w} 2015 \mathrm{roku}$ ). Podobnie, po licznych wahaniach wzrósł odsetek gospodarstw domowych emerytów, którym z powodu problemów finansowych przynajmniej raz nie udało się uiścić w terminie rat kredytu hipotecznego na użytkowane mieszkania. Odsetek ten rósł w latach 2009-2012, po czym zaobserwowano spadek w latach 2013-2015. Analogicznie w latach 2009-2014 rósł odsetek gospodarstw domowych emerytów, którym z powodu problemów finansowych przynajmniej raz nie udało się uiścić w terminie rat kredytów pożyczek innych niż kredyt hipoteczny na użytkowane mieszkania (x10). Pomimo spadku, w 2015 roku odsetek ukształtował się na wyższym poziomie niż w roku bazowym.

Podsumowując, w tabeli 5. zestawiono zmienne uznane za najważniejsze dla zobrazowania sytuacji dochodowej gospodarstw domowych emerytów w badanym okresie. 
TABELA 5.

Podstawowe zmienne obrazujące sytuację ekonomicznej gospodarstw domowych emerytów (obszar 2.) w Polsce w latach 2009-2015

\begin{tabular}{|c|c|c|c|c|c|}
\hline Zmienna & $\begin{array}{c}\mathbf{2 0 0 9} \\
\mathbf{( w ~ \% )}\end{array}$ & $\begin{array}{c}\mathbf{2 0 1 5} \\
\mathbf{( w} \% \mathbf{~})\end{array}$ & $\begin{array}{c}\text { Zmiana w ba- } \\
\text { danym okresie } \\
\text { (w pp.) }\end{array}$ & $\begin{array}{c}\text { Wpływ na sytua- } \\
\text { cję mieszkaniową }\end{array}$ & $\begin{array}{c}\text { Ocena } \\
\text { zmiany }\end{array}$ \\
\hline $\mathrm{x} 5$ & 60,8 & 63,7 & $+2,90$ & $\mathrm{~s}$ & + \\
$\mathrm{x} 6$ & 35,00 & 35,50 & $+0,50$ & $\mathrm{~s}$ & + \\
$\mathrm{x} 7$ & 1,30 & 1,40 & $+0,10$ & $\mathrm{~s}$ & + \\
$\mathrm{x} 8$ & 23,2 & 23,3 & $+0,10$ & $\mathrm{~d}$ & - \\
$\mathrm{x} 9$ & 7,10 & $8,00^{*}$ & $+0,90$ & $\mathrm{~d}$ & - \\
$\mathrm{x} 10$ & 8,00 & $9,00^{*}$ & $+1,00$ & $\mathrm{~d}$ & - \\
\hline
\end{tabular}

Objaśnienia: s - stymulanta; d - destymulatna; „,+” - wpływ pozytywny, „,- ” - wpływ negatywny; * - dane za rok 2014 (brak danych za rok 2015); x5 -relacja przeciętnej miesięcznej emerytury brutto z pozarolniczego systemu ubezpieczeń społecznych do przeciętnego wynagrodzenia w gospodarce narodowej; x6 - relacja przeciętnej miesięcznej emerytury brutto z Kasy Rolniczego Ubezpieczenia Społecznego do przeciętnego wynagrodzenia w gospodarce narodowej; 77 - relacja przeciętnego miesięcznego dochodu rozporządzalnego na 1 osobę w gospodarstwach domowych emerytów (w zł) do średniego minimum socjalnego dla jednoosobowych gospodarstw emeryckich; x8 - udział wydatków mieszkaniowych w ogóle wydatków emerytalnych gospodarstw domowych; $\mathrm{x} 9 / 10$ - \% gospodarstw domowych emerytów deklarujących, że w roku poprzedzającym badanie ze względu na problemy finansowe przynajmniej raz nie udało się uiścić w terminie stałych opłat związanych z użytkowaniem mieszkania (x9) lub rat kredytów, pożyczek innych niż kredyt hipoteczny na użytkowane mieszkanie (x10).

Źródło: opracowanie własne na podstawie: [Emerytury i renty..., 2009, 2010, 2011, 2012, 2013, 2014, 2015].

Ogółem w badanym okresie poprawie uległa sytuacja dochodowa gospodarstw domowych emerytów, jednak wzrósł odsetek gospodarstw domowych, które miały trudności z regularną spłatą zobowiązań wynikających z użytkowania mieszkania.

\section{Warunki mieszkaniowe gospodarstw domowych emerytów w latach 2009-2015}

W obszarze oceny warunków mieszkaniowych posłużono się następującymi zmiennymi: wielkość przestrzeni mieszkalnej (przeciętna powierzchnia użytkowa zajmowana przez gospodarstwo domowe, przeciętna liczba osób przypadająca na 1 pokój), poziom wyposażenia w urządzenia i instalacje techniczno-sanitarne (wodociąg, ustęp spłukiwany, łazienkę, ciepłą wodę, centralne ogrzewanie), odsetek gospodarstw deklarujących brak możliwości ogrzewania mieszkania odpowiednio do potrzeb, stan mieszkań zajmowanych przez gospodarstwa domowe emerytów (w tym ocena ich: jakości, położenia, wielkości i komfortu cieplnego). 
W tabeli 6. przedstawiono przeciętną liczbę osób przypadającą na jeden pokój w takim gospodarstwie domowym (x11) oraz przeciętną powierzchnię użytkową zajmowaną przez gospodarstwo domowe emerytów (x12).

TABELA 6.

Przeciętna liczba osób przypadająca na jeden pokój oraz przeciętna powierzchnia użytkowa mieszkania zajmowanego przez gospodarstwo domowe emerytów w Polsce w latach 2009-2015

\begin{tabular}{|c|c|c|}
\hline Rok & $\begin{array}{l}\text { Przeciętna powierzchnia } \\
\text { użytkowa mieszkania } \\
\qquad\left(\mathrm{w}^{2}\right)\end{array}$ & $\begin{array}{c}\text { Przeciętna liczba osób } \\
\text { przypadająca na jeden po- } \\
\text { kój (w os./pokój) }\end{array}$ \\
\hline 2009 & 64,13 & 0,75 \\
\hline 2010 & 66,5 & 0,72 \\
\hline 2011 & 66,9 & 0,72 \\
\hline 2012 & 66,2 & 0,73 \\
\hline 2013 & 67,1 & 0,7 \\
\hline 2014 & 68,3 & 0,7 \\
\hline 2015 & 69,2 & 0,69 \\
\hline
\end{tabular}

Źródło: opracowanie własne na podstawie: [Emerytury i renty..., 2009, 2010, 2011, 2012, 2013, 2014, 2015].

W analizowanym okresie znacznie wzrosła przeciętna powierzchnia użytkowa mieszkania zajmowanego przez gospodarstwo domowe emerytów. Poza niewielkim spadkiem odnotowanym w 2012 roku, wzrost był systematyczny. Ogółem średnia powierzchnia mieszkania gospodarstwa domowego emerytów w 2015 roku wyniosła 69,2 m², co w porównaniu z wartością z 2009 roku $\left(64,13 \mathrm{~m}^{2}\right)$ oznacza wzrost o 8\%. Wskaźnik był silnie ujemnie skorelowany ze wskaźnikiem liczby osób przypadających na jeden pokój (współczynnik korelacji liniowej Pearsona wynosił -0,935 i był istotny statystycznie na poziomie $\alpha=0,01)$. Zmienne przyniosły podobną wartość informacyjna. Wraz ze wzrostem średniej powierzchni użytkowej przypadającej na jedno gospodarstwo domowe spadła liczba osób przypadających na jeden pokój.

W analizowanym okresie wzrósł stan wyposażenia mieszkań emerytów w instalacje techniczno-sanitarne (tabela 7.). 
TABELA 7.

Odsetek mieszkań emerytów wyposażonych w wybrane instalacje techniczno-sanitarne

\begin{tabular}{|l|c|c|c|c|c|}
\hline 2009 & Wodociąg & $\begin{array}{c}\text { Ustęp spłu- } \\
\text { kiwany }\end{array}$ & Lazienka & $\begin{array}{c}\text { Ciepła } \\
\text { woda bie- } \\
\text { żąca }\end{array}$ & $\begin{array}{c}\text { Centralne } \\
\text { ogrzewanie }\end{array}$ \\
2010 & 98,6 & 92,1 & 91,5 & 91,6 & 79,1 \\
2011 & 98,8 & 93,8 & 92,9 & 92,6 & 80,8 \\
2012 & 98,8 & 94,5 & 93,7 & 93,7 & 80,9 \\
2013 & 98,9 & 94,7 & 94 & 93,8 & 82,3 \\
2014 & 99,2 & 95,4 & 94,9 & 94,4 & 83,9 \\
2015 & 99,3 & 95,9 & 95,5 & 95,2 & 83,4 \\
\hline
\end{tabular}

Źródło: opracowanie własne na podstawie: [Emerytury i renty..., 2009, 2010, 2011, 2012, 2013, 2014, 2015].

W analizowanym okresie wzrosło wyposażenie mieszkań zajmowanych przez emerytów we wszystkie analizowane instalacje techniczno-sanitarne. Wskazane zmienne były ze sobą wysoko skorelowane (na poziomie istotności 0,01 ). Największy wzrost wyposażenia mieszkań w latach 2009-2015 odnotowano w odniesieniu do centralnego ogrzewania (x13, zmiana o 5,7 pp.) oraz dostępu do spłukiwanego ustępu (zmiana o 4,6 pp.). W 2015 roku niespełna 1\% gospodarstw domowych emerytów nie miało dostępu do wodociagu, ponad 4\% do łazienki i ciepłej wody bieżącej, zaś około 3\% do spłukiwanego ustępu. Około 15\% badanych gospodarstw domowych nie miało dostępu do centralnego ogrzewania. Ogółem w zakresie wyposażenia technicznego mieszkań zaszły pozytywne zmiany.

W analizowanym okresie spadł odsetek gospodarstw domowych emerytów deklarujących brak możliwości ogrzewania mieszkania odpowiednio do potrzeb (x14). Tendencja była spadkowa w całym analizowanym okresie. W 2009 roku ponad co piate gospodarstwo domowe (22\%) deklarowało brak możliwości ogrzewania mieszkania odpowiednio do potrzeb, zaś w 2015 roku już 8,9\%. W całym okresie z roku na rok odsetek wskazań spadał. Sytuacja poprawiała się wyraźnie dynamicznie w latach 2013-2015 (spadek w ciagu dwóch lat z 16 do 8,9\% odpowiednio o 3,2 oraz 3,9 pp. w 2014 i $2015 \mathrm{roku})$.

Podobnie w analizowanym okresie spadł odsetek emerytalnych gospodarstw domowych deklarujących negatywny stan zajmowanych mieszkań, w tym: posiadających przeciekający dach, zawilgocone ściany, podłogi, fundamenty, butwiejące okna i podłogi; narażonych na nadmierny hałas pochodzący od sąsiadów lub z zewnątrz; położonych w szczególnie uciążliwym otoczeniu ze względu na zanieczyszczenie środowiska (np.: pył, dym, nieprzyjemne zapachy, zanieczyszczona woda); położonych w rejonie zagrożonym przestępczościa, przemoca, wandalizmem oraz w regionie o złej infrastrukturze; nieposiadających balkonu, zbyt małych, zbyt dużych. W analizowanym 
okresie wzrosła liczba mieszkań wyposażonych w balkon (taras) lub ogródek z 78,9\% do $82,3 \%$ gospodarstw domowych emerytów. Wzrosła liczba gospodarstw domowych deklarujących, że zajmowane mieszkanie jest wystarczająco ciepłe zimą (x15, wzrost z 80,4 do $85,2 \%$ ) oraz, że jest wystarczająco chłodne latem (z 72,7 do 77,2\%). Zmianę pozostałych wskaźników przedstawiono na wykresie 3 .

WYKRES 3.

\section{Odsetek mieszkań gospodarstw domowych emerytów niespełniających wy- branych standardów jakościowych}

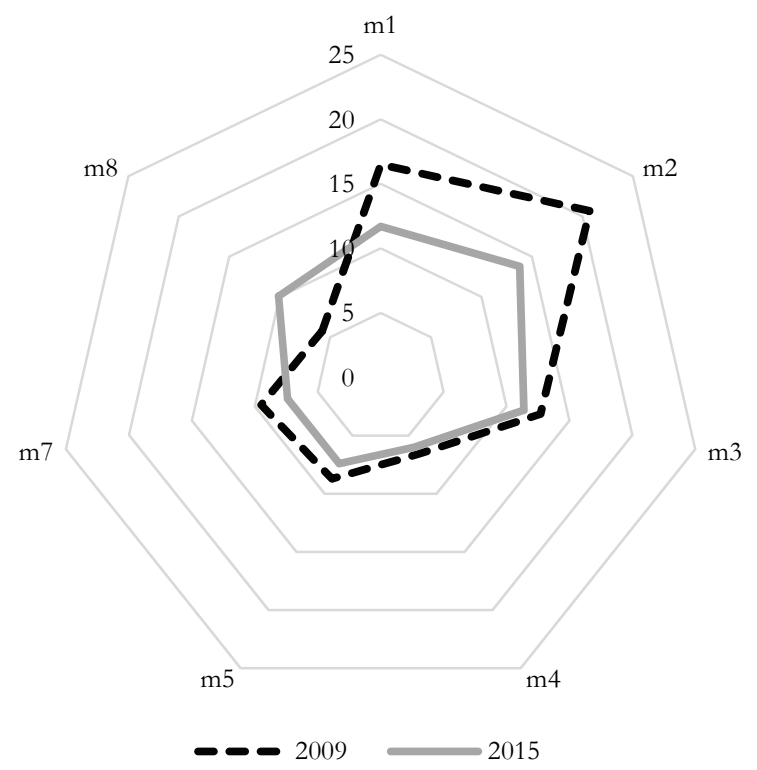

Objaśnienia: m1 - odsetek mieszkań o przeciekającym dachu, zawilgoconych ścianach, podłogach, fundamentach, butwiejących oknach i podłogach; m2 - odsetek mieszkań narażonych na nadmierny hałas pochodzący od sąsiadów lub z zewnątrz; m3 - odsetek mieszkań położonych w szczególnie uciążliwym otoczeniu ze względu na zanieczyszczenie środowiska (np. pył, dym, nieprzyjemne zapachy, zanieczyszczona woda); $\mathrm{m} 4$ - odsetek mieszkań położonych w rejonie zagrożonym przestępczością, przemoca, wandalizmem; m5 - odsetek mieszkań położonych w rejonie o złej infrastrukturze; m6 - odsetek mieszkań ocenianych jako zbyt małe; m7 - odsetek mieszkań ocenianych jako zbyt duże.

Źródło: opracowanie własne na podstawie: [Emerytury i renty..., 2009, 2010, 2011, 2012, 2013, 2014, 2015].

Zgodnie z wykresem 3., w analizowanym okresie spadł odsetek gospodarstw domowych emerytów deklarujących poszczególne problemy związane z warunkami mieszkaniowymi. Spadek był szczególnie znaczący w odniesieniu do mieszkań narażonych na hałas (spadek o 6,9 pp.). Można zauważyć, że wzrost wskazań nastąpił w jednym 
z analizowanych obszarów (m7). Wzrosła liczba gospodarstw domowych emerytów uznających, że mieszkanie jest zbyt duże do ich potrzeb. Liczba wskazań w tym zakresie wykazała istotną na poziomie 0,05 korelację ze średnią powierzchnią mieszkania zajmowanego przez gospodarstwa domowe emerytów (współczynnik korelacji liniowej Pearsona $=0,862$ ). Oznacza to, że wzrost średniej powierzchni mieszkania współwystępował z rosnącym odsetkiem emerytów uznających, że zajmowane przez nich mieszkanie jest zbyt duże. Odzwierciedla to negatywną zmianę, biorąc pod uwagę wysoki udział kosztów związanych z utrzymaniem mieszkania w wydatkach emerytalnych gospodarstw domowych.

Podsumowując, wybrano najważniejsze zmienne - kierując się ich wartością informacyjną, przesłankami merytorycznymi oraz poziomem zmienności - obrazujące zmianę warunków mieszkaniowych gospodarstw domowych emerytów w badanym okresie (tabela 8.).

TABELA 8.

Podstawowe zmienne obrazujące warunki mieszkaniowe gospodarstw domowych emerytów (obszar 1.) w Polsce w latach 2009-2015

\begin{tabular}{|c|c|c|c|c|c|}
\hline Zmienna & $\begin{array}{l}2009 \\
\text { roku } \\
(\mathrm{w} \%)\end{array}$ & $\begin{array}{c}2015 \\
\text { rok } \\
(\mathrm{w} \%)\end{array}$ & $\begin{array}{c}\text { Zmiana w ba- } \\
\text { danym okresie } \\
\text { (w pp.) }\end{array}$ & $\begin{array}{l}\text { Wpływ na sytua- } \\
\text { cję mieszka- } \\
\text { niową }\end{array}$ & $\begin{array}{l}\text { Ocena } \\
\text { zmiany }\end{array}$ \\
\hline $\mathrm{x} 11$ & 0,75 & 0,69 & $-0,06$ & $\mathrm{~d}$ & + \\
\hline $\mathrm{x} 12$ & 64,13 & 69,2 & $+5,07$ & $\mathrm{n}$ & - \\
\hline x3 & 79,1 & 84,8 & $+5,7$ & s & + \\
\hline $\mathrm{x} 4$ & 22,0 & 8,9 & $-13,1$ & d & + \\
\hline $\mathrm{x} 5$ & 80,4 & 85,2 & $+4,8$ & s & + \\
\hline $\mathrm{m} 1$ & 16,5 & 11,7 & $-4,8$ & d & + \\
\hline $\mathrm{m} 6$ & 9,5 & 7,4 & $-2,1$ & d & + \\
\hline $\mathrm{m} 7$ & 5,8 & 10,1 & 4,3 & d & - \\
\hline
\end{tabular}

Objaśnienia: s - stymulanta; d - destymulatna; ,,+”-wpływ pozytywny; „,- ” - wpływ negatywny; x1 - przeciętna liczba osób przypadająca na jeden pokój; x2 - przeciętna powierzchnia użytkowa $\mathrm{w} \mathrm{m}^{2}$; $\mathrm{x} 3$ - odsetek gospodarstw domowych posiadających centralne ogrzewanie; x4 - odsetek gospodarstw domowych emerytów deklarujących brak możliwości ogrzewania mieszkania odpowiednio do potrzeb; x 5 - odsetek gospodarstw domowych deklarujących, że zajmowane mieszkanie jest wystarczająco ciepłe zima; $\mathrm{m} 1$ - odsetek mieszkań o przeciekającym dachu, zawilgoconych ścianach, podłogach, fundamentach, butwiejących oknach i podłogach; m6 - odsetek mieszkań ocenianych jako zbyt małe; m7 - odsetek mieszkań ocenianych jako zbyt duże.

Źródło: opracowanie własne na podstawie: [Emerytury i renty..., 2009, 2010, 2011, 2012, 2013, 2014, 2015].

Badanie wykazało, że w obszarze warunków mieszkaniowych sytuacja gospodarstw domowych emerytów poprawiła się w Polsce w latach 2009-2015. Jedyną zaobserwowana, negatywną zmianą był wzrost odsetka gospodarstw domowych deklarujących, że zajmowane mieszkanie jest zbyt duże. To z kolei rzutuje na interpretację 
zmiennej x12, obrazującej przeciętna powierzchnię mieszkania, którą ogólnie uznaje się za stymulantę sytuacji mieszkaniowej. $\mathrm{Na}$ tej podstawie można wnioskować, że zmienna ma charakter nominanty, a jej poziom przekroczył wartość graniczna, do której jej wzrost można oceniać jako pozytywny dla sytuacji mieszkaniowej emerytów. Tym samym dalszy wzrost przeciętnej powierzchni mieszkań gospodarstw domowych emerytów należy interpretować jako zmianę negatywna.

\section{Podsumowanie}

Podsumowując, w obszarze struktury demograficznej gospodarstw domowych emerytów w latach 2009-2015 zaobserwowano zmiany, które pod względem kształtowania się sytuacji mieszkaniowej osób starszych należy ocenić negatywnie. Zmalała przeciętna liczba osób w gospodarstwach domowych emerytów, jednocześnie rośnie liczba gospodarstw domowych jednoosobowych. Równocześnie zwiększył się udział osób starszych w strukturze społecznej, co stanowi istotne wyzwanie w stosunku do polityki mieszkaniowej w kraju. Pozytywną zmianą okazała się poprawa wskaźników subiektywnej oceny stanu zdrowia, co stanowi szansę na dłuższe utrzymanie samodzielności osób starszych w miejscu zamieszkania.

W analizowanym okresie nastąpiła poprawa relacji wysokości emerytur do średniego poziomu dochodów w gospodarce narodowej. Jednak nadal wskaźnik ten jest na niskim poziomie, w szczególności dla gospodarstw domowych pobierających emerytury z Kasy Rolniczego Ubezpieczenia Społecznego. Zaobserwowano negatywne zmiany dotyczące wzrostu zaległości w opłatach gospodarstw domowych związanych z utrzymaniem mieszkania.

Wskaźniki oceny warunków mieszkaniowych gospodarstw domowych emerytów w latach 2009-2015 w większości uległy poprawie. Jednocześnie wzrost średniej powierzchni mieszkania przypadającej na gospodarstwo domowe połączony ze wzrostem odsetka osób oceniających je jako zbyt duże stwarza problemy interpretacyjne, gdyż można przypuszczać - również uwzględniając rosnące problemy z bieżącym regulowaniem zobowiązań mieszkaniowych w badanej grupie gospodarstw domowych - że posiadają one problemy z utrzymaniem tak dużej przestrzeni mieszkalnej.

W prezentowanym badaniu zwrócono uwagę na tendencję zmian w zakresie sytuacji mieszkaniowej emerytalnych gospodarstw domowych w czasie. Obok niej, także jest istotna ocena dysproporcji między sytuacją mieszkaniowa gospodarstw domowych emerytów a sytuacją innych gospodarstw domowych, zwłaszcza w odniesieniu do kształtowania zasad polityki spójności, zważając na fakt, iż społeczeństwa o większych nierównościach z reguły w większej mierze są narażone na problemy społeczne [Poskrobko, Zielińska, 2015, s. 283]. Badania takie powinny stanowić dalszy etap prowadzonych analiz. 


\section{Literatura}

Błędowski P., Szatur-Jaworska B., Szweda-Lewandowska Z., Kubicki P., 2012, Raport na temat sytuacji osób starszych w Polsce, Instytut Pracy i Spraw Socjalnych, Warszawa.

Emerytury $i$ renty w 2009, 2010, 2011, 2012, 2013, 2014, 2015 r., Główny Urząd Statystyczny, Warszawa.

http://www.polsenior.iimcb.gov.pl (data wejścia: 10.05.2017).

http:/ / appsso.eurostat.ec.europa.eu (data wejścia: 20.06.2017).

Marcinkiewicz J., Matel A., 2017, Analiza dostepności mieszkań w miastach wojewódzkich Polski z wykoraystaniem metody TOPSIS, Prace Naukowe Uniwersytetu Ekonomicznego we Wrocławiu, nr 475, Wrocław.

Poskrobko T., Zielińska A., 2015, Innowacje w krajach rozwijajacych sie a zrównoważony rozwój, Prace Naukowe Uniwersytetu Ekonomicznego we Wrocławiu, nr 409, Wrocław.

Prognoz̧a ludności na lata 2014-2050. Studia i analizy statystyczne, 2014, Główny Urząd Statystyczny, Warszawa.

Rocznike demograficzny, 2016, Główny Urząd Statystyczny, Warszawa.

Rocznik Statystyczny Rzeczpospolitej Polskiej, 2010, 2011, 2012, 2013, 2014, 2015, 2016, Główny Urząd Statystyczny, Warszawa.

Ustawa z. 11 września 2015 r. o osobach starszych, Dz. U. 2015, poz. 1705.

Zrałek M., 2012, Zaspokojenie potrzeb mieszkaniowych osób starszych. Dylematy i kierunki zmian, [w:] O sytuacji ludzi starszych, J. Hrynkiewicz (red.), Rządowa Rada Ludnościowa, t. III, Warszawa. 